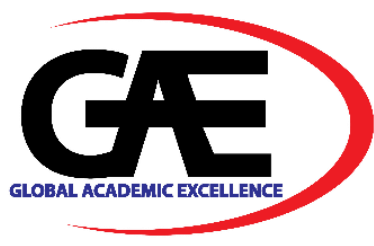

\title{
A SEGMENT STUDY OF MORAL CRISIS ON SOCIAL MEDIA AND ONLINE USING THE ARTIFICIAL INTELLIGENCE APPLICATION: A WAKE-UP CALL
}

\author{
Nor 'Adha Ab Hamid ${ }^{1 *}$, Azizah Mat Rashid ${ }^{2}$, Mohd Farok Mat Nor ${ }^{3}$
}

Associate Professor, Faculty of Syariah and Law, Kolej Universiti Islam Antarabangsa Selangor (KUIS), Bandar Seri Putra, 43000 Kajang Selangor

Email: noradha@kuis.edu.my

2,3 Lecturer, Faculty of Syariah and Law, Kolej Universiti Islam Antarabangsa Selangor (KUIS), Bandar Seri

Putra, 43000 Kajang Selangor

Corresponding Author

\section{Article Info:}

\section{Article history:}

Received date: 15.01 .2021

Revised date: 15.02 .2021

Accepted date: 01.03.2021

Published date: 05.03.2021

\section{To cite this document:}

Ab Hamid, N 'A., Mat Rashid, A., Mat Nor, M. F. (2021). A Segment Study of Moral Crisis on Social Media and Online Using the Artificial Intelligence Application: A Wake-up Call. International Journal of Law, Government and Communication, 6 (22), 36-44.

DOI: $10.35631 /$ IJLGC.622003.

This work is licensed under CC BY 4.0

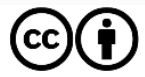

Abstract:

The development of science and technology is always ahead and has no point and seems limitless. Although human beings are the agents who started this development but eventually faced with a bitter situation which can sacrifice human moral, right and interest of our future. Shariah criminal offenses nowadays can not only occur or be witnessed by a person in a meeting physically with the perpetrator. As a result of technological developments, such behavior can occur and can be witnessed in general by larger groups. Although the illegal treatment which is not in accordance with sharia law and the moral crisis issues happening surrounding us and is rampant on social media, no enforcement is done on perpetrators who use social media medium. According to sharia principles, something that is wrong should be prevented and it is the responsibility of all Muslim individuals. But what is happening today, some Shariah criminal behavior, especially in relation to ethics, can occur easily using facilities technology driven by technological ingenuity. If the application of existing legal provisions is limited and has obstacles for enforcement purposes, then the problem needs to be overcome due to development the law should be in line with current developments. The study aims to identify a segment and cases of the moral crisis on social media and online using the artificial intelligence (AI) application and to identify the needs for shariah prevention. This thesis uses qualitative approaches, adopts library-based research, and, by content analysis of documents, applies the literature review approach. The findings show that the use of social media and AI technology has had an impact on various issues such as moral crisis, security, misuse, an intrusion of personal data, and the construction of AI beyond human control. Thus, the involvement and cooperation of various parties are needed in regulating and addressing issues that arise as a result of the use of social media and AI technology in human life. 


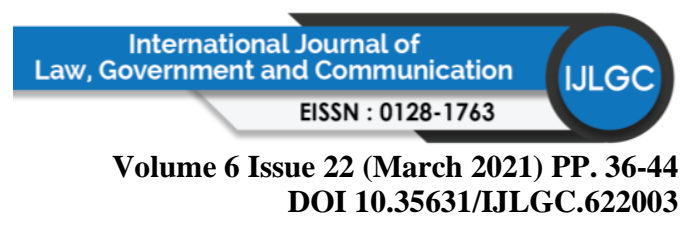

Keywords:

Shariah, Criminal, Offence, Social Media, Artificial Intelligence

\section{Introduction}

Today the development of information technology is very rapid, especially in the use of the internet, which is due to the development in the field of education and knowledge. Due to the developments, our society today is experiencing a very alarming moral crisis as it is tainted by various forms of moral decay because of the misuse of social media and AI technology. It is a long wake-up call to develop a cyber-crime prevention system or computer security system in cyberspace or in internet use so that the use or access of the internet feels more secure and comfortable, so that users no longer feel worried about using the internet, and not misused by certain parties who allow to commit cybercrime or crimes in cyberspace. Similar feelings also being asked as our worries on the misuse of social media and AI technology could affect negatively on the morality of our society. This is another wake-up calls for the authorities on the needs to strengthen the laws as to curb the moral crisis by misusing the social media and AI technology.

Moral crisis is defined in the 'Kamus Dewan Edisi Keempat' as a deterioration (damage) of character that has reached an alarming level. Miskawaih defines morality as a matter or psychological situation that encourages a person to do things easily without thinking and requires careful planning (Mohd. Nasir, 2005). In addition to the importance of morality as an indicator in the formation of civilization, the construction of good morals is also related to the question of worship. Allah SWT says in the Qur'an (Az-Zariyat: 56) which means, 'I created the jinn and humankind only that they might worship Me.' Allah SWT calls His faithful servants to accept Islam and practice its teachings thoroughly with His words which means ' $\mathrm{O}$ believers! Enter into Islam wholeheartedly and do not follow Satan's footsteps. Surely he is your sworn enemy' (al-Baqarah: 208). What can be understood here, every human practice and deed should be based on the teachings of Islam as a whole covering aspects of worship, morality, muamalah and so on.

\section{Methodology}

The article aims to identify a segment of moral crisis on social media and online using the artificial intelligence (AI) application and to identify the needs for shariah prevention. This thesis uses qualitative approaches, adopts library-based research and, by content analysis of documents, applies the literature review approach. The findings show that the use of social media and AI technology has had an impact on various issues such as security, misuse, intrusion of personal data and the construction of AI beyond human control. As regards to the discussion in the article, the impact on moral crisis on social media and online using the artificial intelligence (AI) is apparent. Thus, the involvement and cooperation of various parties is needed in regulating and addressing issues on moral crisis that arise as result of the use of social media and AI technology in human life. 


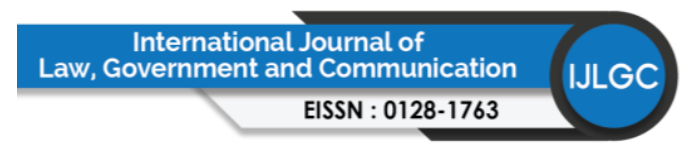

Volume 6 Issue 22 (March 2021) PP. 36-44

DOI 10.35631/IJLGC.622003

\section{Analysis and Discussion}

\section{The Social Media and Artificial Intelligence (AI) Technology}

Social media is an application that uses Web 2.0 technology and gives users the opportunity to produce materials in various forms such as text, audio and video that can be shared with other users. Social media can also be interpreted as an application that combines various social functions such as cooperation, sharing, freedom, openness, interactive and involvement (Mohammad Rezal, 2016). The study from Muhammad Hazwan Johari (2019) focuses on examining the progress of social media today which is one of the mediums of communication, especially among the world and the Muslim community. It discussed the definition of social media as a tool or mediator of interpersonal relationships. It is a concern to look at the development of the use of social media that can make the Muslim community become negligent with worldly activities until the affairs of the hereafter are forgotten. This will lead to the moral crisis.

In recent years, social media has been seen merging into one type of platform, which is social networking. Social networks arise from the ability of consumers to represent themselves and their interests in social platforms and intensify activities with others in the channel of social media. 2008 is seen as the year of social media development, especially networking social: Facebook being a major player, MySpace changed its focus to music and movies, Friendster is a leader in Southeast Asia. Nowadays, online social networks are becoming as popular around the world as a place for those who want something to meet those who have similar interests, express feelings, and act. It becomes a utility social to manage relationships with $96 \%$ visiting friends' networking sites them while two-thirds spend time managing their profile alone (Siti Ezaleila Mustafa \& Azizah Hamzah, 2010).

The results of the study by Muhammad Hazwan Johari (2019) discuss the importance of using social media as a medium of communication, medium of da'wah, and medium to convey information easily quickly and accurately. The benefits of using the medium forms especially to the Muslim community to think creatively, critically and give birth to a smart Muslim community. The widespread use of social media has an impact on the Muslim community in terms of political, economic, social, and educational. The study also discusses the manners of the use of social media according to Islam, the ethics of using social media based on propositions, the efforts of certain parties in preserving the effective use of social media and the challenges faced by the Muslim community, especially in preserving the use of social media. The study also emphasized the importance of parties that need to work together in preserving the effective function of social media.

The use of artificial intelligence or AI technology is becoming more widespread. From smartphones, computers, driverless cars, drones to the use of robots have changed the landscape of human life. Artificial Intelligence (AI) is a computer science that focuses on the ability of machines in imitating the intelligence of human behavior. AI allows computers to process a lot of information and data as well as provide computer-based conclusions in a relatively short and fast time. Simply put, Kerr (2017) defines AI as the intelligence displayed by a system, machine, or program. The term Artificial Intelligence (AI) was first used by one of Stanford University professors John McCarthy in 1956 in a conference on computing in Dartmouth, USA (Russell \& Norvig, 2016). In this conference, they tried to discuss how computers are capable of imitating or following human ingenuity. The scientists involved in 


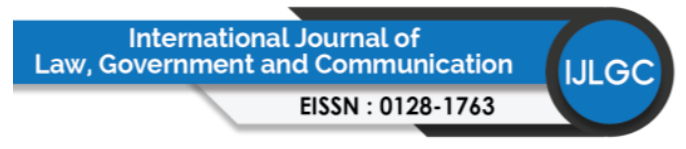

Volume 6 Issue 22 (March 2021) PP. 36-44

DOI 10.35631/IJLGC.622003

this discussion are Allen Newel, Herbert Simon, Marvin Miskey, Oliver Selfridge and John McCarthy. McCarthy's idea of AI next came to the attention of a mathematician, Alan Turing. Turing issued a hypothesis and question regarding the ability of machines to think. He has conducted several related tests and he found that machines capable of thinking and learning just like humans (Amrizal \& Aini, 2011).

According to Dahria (2008), the test was later named as the Turing test which was conducted using AI devices; one operator and one terminal. If the operator cannot distinguish himself talking to a machine or a human, then the test successful and it is proven that the machine is also as intelligent as a human. Artificial intelligence is divided into three types or levels. First, Artificial Narrow Intelligence (ANI). ANI is an AI system capable of running something simple and straightforward. For example, ability to detect car fuel shortages and give a warning signal to the driver by flashing lights on the car dashboard. Second, Artificial General Intelligence (AGI). Artificial intelligence that has reached this level is capable and comparable to thinking with humans and even able to think faster than humans. Calculation in large quantities and involves the process of counting calculations such as division, multiplication, addition, subtraction, power source, etc. is difficult for humans to calculate in a short time. However, machines with AGI capable of counting in 10 million times faster than humans. Lastly is Artificial Super Intelligence (ASI). Breast milk is an artificial intelligence system able to transcend human thinking and ingenuity in almost all disciplines and it is still unclear if any machines using breast milk were created (Strelkova \& Pasichnyk 2017). Moreover, the basis of this AI is algorithm. Artificial intelligence is designed based on scientific findings such as statistics mathematics and biology.

The AI device works based on the models that have been designed including Ant Colony Algorithm, Immune Algorithm, Fuzzy Algorithm, Decision Tree, Genetic Algorithm, Particle Swarm Algorithm, Neural Network, Deep Learning, Support Vector Machine and Artificial Neural Network (Alsedrah, 2018). Apart from the framework of different AI devices, in order to make a computer a smart machine and able to behave like a human, knowledge base factors and engine inference need to be included in the AI system. This knowledge base factor includes facts theories and the relationship between the two. Engine inference factors include the ability to draw conclusions based on knowledge and experience. The combination of these two factors creates artificial intelligence (AI) that performs input and output processes. Machines will be able to receive and interpret data entered by humans as well as provide answers sought by humans in a timely manner (Dahria, 2014). Although this AI is still in the early stages of development, but the use of AI has expanded and led to a variety of great technological inventions. The reality is that the use of smartphones, tablets, laptops, drones, automatic machines, self-driving vehicle and robots are examples of the use of AI. The same goes for social media applications like Facebook, YouTube; Google search application, Yahoo; Waze navigation app, Google Maps; and Alexa, Siri, Cortana, Google Assistant smart voice applications are examples of AI implemented in various forms. In addition, AI was also developed to facilitate daily tasks and human needs including roles for convenience at home, socializing friends, automotive, industry and as a tool of war. According to Chang (2020), the use of AI has increased dramatically and is widely used in automotive, data identification, patient data processing, merchandise regulation, mapping, system maintenance, cyber security, HR systems and analysis in medicine. This shows that the existence of AI changes the landscape of human social life in carrying out daily activities and occupations. 


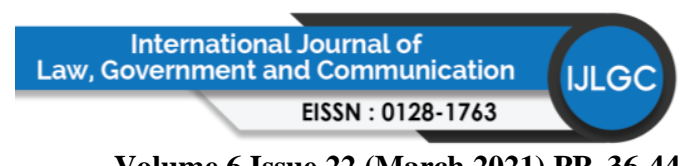

Volume 6 Issue 22 (March 2021) PP. 36-44

DOI 10.35631/IJLGC.622003

The term intelligence refers to the ability to acquire and apply skills and knowledge in solving existing problems. Artificial intelligence is a program used to see the ability of machines to learn human behavior and provide responses or reactions like humans (Shabbir \& Anwer, 2015). This program is embedded in software machines or robots so that it can act like what humans do and think in accordance with what humans want. Human and machine intelligence have many significant differences. Humans are smart and skilled in solving problems because humans have experience and knowledge. The level of human intelligence also determines the quality of thoughts and actions performed by humans (Gratton et al., 2018). The more experience and knowledge gained, the more problems that can be solved (Dahria, 2008). However, the intelligence of the human mind also has its limitations. Humans do not have the ability to find information such as the latest info quickly without relying on machines such as computers. The function of a computer is initially just to process data and show the results of data collection. However, technological advances today have improved the functionality of computers where not only can process data but also be able to provide more accurate results to users. This artificial intelligence technique helps computers process information like humans. Through this approach, efforts to make computers that can think like humans try to be developed (Amrizal \& Aini, 2011).

As a conclusion, the development of science and technology is always ahead and has no point. Although human beings are the agents who started this development but eventually faced with a bitter situation which can sacrifice human rights interests and future. In fact, uncontrolled developments in the field of AI can result in the extinction of human civilization. Without denying also the potential and benefits of AI can make the quality of human life improve (Aliff Nawi. (2019). However, AI also has weaknesses when compared to natural intelligence (Human Intelligence or Natural Intelligence) considering that human intelligence/natural intelligence is obtained through an evolutionary process, while AI itself is a product of natural intelligence (Prastiwi, CHW \& Nia Pujiawati. (2019).

\section{The Moral Crisis on Social Media and Online Using the Artificial Intelligence Application}

Aminuddin Basir and Ahmad (2009) found in the study that the freedom of the media to get the message and convey it needs to move in line with the existing legal provisions and adhere to high morals and ethics to safeguard the interests of the public and ensure national security. Researchers discuss issues that need to be taken seriously where the freedom and openness of society in disseminating information on social media that affects the credibility and dignity of a person should be preserved. The study examines the existing legal provisions and is based on the principles of Islam to curb the issue.

The study by Mohamad Afandi Md Ismail (2019) examines the social problems that are LGBT symptoms faced by Malaysia. The issue of the existence of legislation regarding the LGBT symptoms is seen as quite vague although it is clear the symptoms are a common offense, especially according to Islamic law. Researchers also outlined the efforts of the parties in various way but the efforts were not very effective, in fact made these groups more aggressive, and appeared openly defending their human rights as individuals. The study suggests some steps that can be taken to overcome these symptoms as appropriate measures in addressing the LGBT issue and based on the legal and enforcement approach.

Mahfudzah Mohamad (2015) discussing the issue of symptoms of behavior and habits that are contrary to the normal life system of a human being has become a common thing in the world 


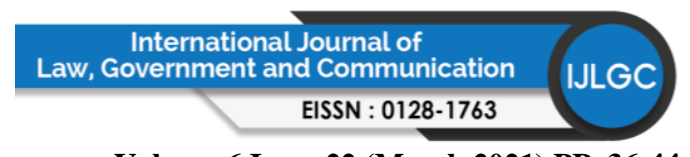

Volume 6 Issue 22 (March 2021) PP. 36-44

DOI 10.35631/IJLGC.622003

in general and Malaysia in particular. In fact, this issue is being fought internationally through the United Nations Human Rights Convention (UNHRC) and is supported by the world's great nations. LGBT symptoms have become a way of life accepted by the outside community and are now permeating into the life of the Muslim community in Malaysia. These symptoms must be curbed to ensure the sustainability of the social life of the community in Malaysia. Various issues and problems arise from claims of this group. In line with the development of LGBT groups in Malaysia, there are several issues that threaten religious values, morals and principles, and sharia criminal law. The study describes the aggressive approach adopted by this group in fighting for their rights.

Looking at the rapid development of the times nowadays, teenagers are especially racing to use social media such as facebook, twitter, instagram and various other social media applications. (Tasnim Rosli, Yogenathan Muniandy, Kamarul Azmi Jasmi, 2019) highlight the issue of today's teenagers who are too obsessed in using social media that can have a negative impact on them, especially on students. Among them are the use of abusive words violence and pornography, following the fashion that is eye-catching, the relationship between family members is getting strained, losing focus and carelessness while driving. The results of the study showed that uncontrolled social media has a negative impact on adolescent behavior. Lack of parental supervision can make this thing worse. It should be emphasized here that the education of worldly knowledge along with the education of the knowledge of the hereafter from the beginning should be given to children to curb this problem.

We can conclude that the digital technologies offer great benefits, but also substantial risks. They may help us to solve some long-standing problems, but they may also create new and even bigger issues. If wrongly used, the moral crisis might be severely accumulated. The foundations on which our society is build might be damaged intentionally or unintentionally within a very short time of period, which may not give us enough opportunities to prepare for or respond to the challenges, such as the serious moral crisis progressively surrounds in our community and big society.

\section{Moral Crisis on Social Media and Online Using the Artificial Intelligence Application: The Needs for Shariah Prevention}

Mahfudzah Mohamad (2015) discusses the ban on LGBT behavior from an Islamic perspective. She also referred to one of the cases that challenged sharia law, namely the case of Muhammad Juzaili bin Mohd Khamis and others against the Negeri Sembilan Government and others. It is so apparent that the activities and moral wrongdoings of this group should be controlled and prevented through the implementation of Syariah Criminal Law. Strict action must be taken so that this group does not disparage and insult sharia law in Malaysia.

Despite the success of research on AI so far, unknowingly AI has also been exploited for its use. Among them is the misuse of AI technology that has threatened the security of the world, especially in terrorist activities armaments and war. By simply using AI technology, a person's face can be transformed into another person and can even be edited into a pornographic action video recording (Harris, 2019). In the United States, humanoid robots that have perfect nature and human-like bodies have been created to be life partners and as sex workers (Frank \& Nyholm, 2017). This shows that the sophistication of AI technology is capable to change the norms of human life. In addition, the use of social media such as Facebook, Whatsapp and Instagram also increases the case of intrusion of personal data. With AI technology, the security 


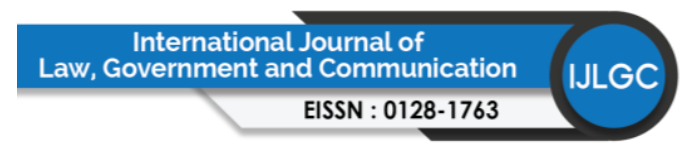

Volume 6 Issue 22 (March 2021) PP. 36-44

DOI 10.35631/IJLGC.622003

of personal data has been manipulated for a specific purpose. For example, cases of misuse of consumer data have been used to influence President Trump's election victory in the United States (Gonzalez, 2017) and several other countries. In Malaysia, the results of the last general election (GE13) were also alleged to be interfering with third parties using personal data of users (Welsh, 2018).

Misuse of personal data is feared to form negative thoughts and determine the tendencies or emotions of society according to political interests in society. Even more frightening, the capabilities of AI technology at the AGI and ASI levels can surpass human capabilities and capabilities. At this stage, the AI system no longer depends on humans with algorithmic code, but it can generate its own algorithm. This phenomenon is causing concern by AI developers around the world including Elon Musk, Bill Gates and Steve Wozniak (Helbing, 2019; Walsh, 2016). They are concerned that current AI technology is evolving drastically and will precede human ingenuity (Müller \& Bostrom, 2016). The same warning was also reminded by Stephen Hawking where he predicted the risk of human race would end when superhuman AI technology was created out of control (Vyas et al. 2018).

\section{Conclusion}

This article and matter discussed raises the question of whether restrictions or barriers that cause no legal action can be taken against the perpetrators while the treatment is clearly contrary to the principles of 'amar makruf and nahi munkar'. For example, behaving rudely in public is a shariah criminal offense and the legal action can be taken if the conduct meets the elements of the offense provided. The question is, can such behavior be prosecuted if it does not happen on the spot public, but recorded and uploaded to social media for public viewing? Public places in the current context should be given a clearer and broader definition taking account the use of social media to be the most effective platform for disseminating information to the public far beyond the scope of the place real public. Lack of clear definitions and incomplete provision of offenses contribute to more widespread sharia criminal behavior and difficult to curb. The provisions of the offenses need to be scrutinized to analyze the elements of the offenses whether they are adequate and covers offenses committed through the current medium. In the event of shariah criminal conduct occurring in social media is out of control due to the weakness of existing legal provisions, hence the goal of prevention wickedness is hard to attain.

It is agreed that cooperation between policy makers, industry and business leaders should be equally involved in developing various better policies to be regulated. In addition to the need to form comprehensive governance, interdisciplinary collaborations and collectives including scientists, engineers, lawmakers, philosopher economists and religious figures are also important to address the impact and risks of AI on society. At the same time, continuous dissemination of information to the community is also needed to ensure that people are aware of the presence of social media and AI in their lives. The findings also show that the use of AI technology has had an impact on various issues such as security, misuse, intrusion of personal data and the construction of AI beyond human control. In conclusion, the use of social media and AI technology invites various issues and problems, but there is no denying that the use of them is also proven to improve the quality of human life in certain aspects. Thus, the involvement and cooperation of various parties is very much needed in regulating and addressing issues of moral crisis that arise from the using of social media and AI technology in human life. Serious exploration of issues and the impact of the use of social media and AI 


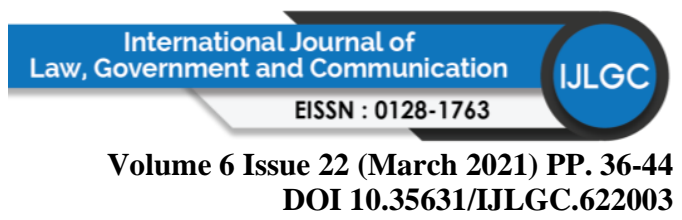

technology on human life morality is crucial. Segments and cases highlighted is seriously a wake-up call.

\section{References}

Al-Quran

Aliff Nawi. (2019). Penerokaan awal terhadap isu dan impak penggunaan teknologi kecerdasan buatan terhadap kehidupan manusia. Asian Journal of Civilizational Studies (AJOCS), 1(4), 24-33.

Alsedrah, M. K. (2017). Running Head : Artificial Intelligent Artificial Intelligence Advanced Analysis and Design : CNIT 380 Instructors : Dr . Hiba Tabbarah \& Mr . Abdullah Abdulghafar Semester: Fall 2017 Section: U1 Mariam Khaled AlSedrah. Researchgate, (December 2017).

Aminudin Basir @ Ahmad, Mohamad Sabri Haron, Nik Yusri Musa, (2009). Kebebasan media komunikasi menurut perspektif Islam. Jurnal Hadhari, 1 (2). pp. 65-82. ISSN 1985-6830

Amrizal, Victor \& Aini, Qurrotul. (2013). Artificial Intellegence. Jakarta Barat: Halaman Moeka Publishing. Artificial Intelligence Strategy. 2018.European Commision,. Jerman. Retrieved from https://ec.europa.eu/digital-singlemarket/en/artificialintelligence (retrieved $17^{\text {th }}$ Feb 2021).

Chang, Jenny. (2020). 50+ Vital Artificial Intelligence Statistics: 2019 \& 2020 Data Analysis \& Market Share. https://financesonline.com/artificial-intelligence-statistics/ (retrieved $18^{\text {th }}$ Feb 2021).

Dahria, Muhammad. (2008). Kecerdasan buatan (Artificial Intelligence). Jurnal Saintikom, 5(2): 185-197.

Frank, L., \& Nyholm, S. (2017). Robot sex and consent: Is consent to sex between a robot and a human conceivable, possible, and desirable? Artificial Intelligence and Law, 25(3), 305-323. doi:10.1007/s10506-017-9212-y.

Gonzalez R. J. (2017), Hacking the citizenry?: Personality profiling, 'big data'and the election of Donald Trump. Anthropology Today, 33(3): 9-12.

Gratton, C., Laumann, T. O., Nielsen, A. N., Greene, D. J., Gordon, E. M., Gilmore, A. W., ... Petersen, S. E. (2018). Functional Brain Networks Are Dominated by Stable Group and Individual Factors, Not Cognitive or Daily Variation. Neuron, 98(2), 439-452.e5. doi:10.1016/j.neuron.2018.03.035.

Harris, D. (2019). Deepfakes: False Pornography Is Here and the Law Cannot Protect You. Duke Law \& Technology Review, 17: 99-127.

Helbing D. (2019) Societal, Economic, Ethical and Legal Challenges of the Digital Revolution: From Big Data to Deep Learning, Artificial Intelligence, and Manipulative Technologies. In: Helbing D. (eds) Towards Digital Enlightenment. Springer, Cham.

Johari, Muhammad Hazwan; Baharuddin, Amirul Syafiq; Ihwani, Siti Suhaila (2019). "Media Sosial dan Kelestarian Penggunaan Menurut Islam" in Jasmi, Kamarul Azmi (Ed.), Prosiding Seminar Sains Teknologi dan Manusia 2019 (SSTM'19) pada 15hb. Disember 2019 di DP3, N29, Fakulti Kejuteraan Kimia dan Tenaga, UTM. Program anjuran Akademi Tamadun Islam, FSSK, UTM, p. 61-86.

Kamus Dewan Edisi Keempat, Dewan Bahasa dan Pustaka Kuala Lumpur, 2007

Kerr, S. (2017). Exploring the impact of artificial intelligence on teaching and learning in higher education. https://doi.org/10.1186/s41039-017-0062-8. (retrieved $-17^{\text {th }}$ Feb 2021). 


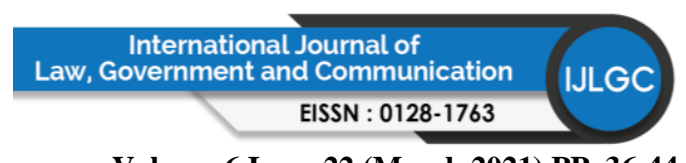

Volume 6 Issue 22 (March 2021) PP. 36-44

DOI 10.35631/IJLGC.622003

Mahfudzah Mohamad, (2015). Lesbian, gay, biseksual dan transgender: perspektif undangundang jenayah syariah. Jurnal Undang-Undang dan Masyarakat, 19 . pp. 29-36. ISSN 1394-7729.

Mohamad Afandi Md Ismail and Mohd Sabree Nasri (2019). Gejala LGBT di Malaysia: Isu dan Cadangan Penyelesaian. Journal of Law and Governance, Vol. 2, 51-65.

Mohammad Rezal Hamzah (2016). Faktor peramal tingkah laku kesihatan di media sosial dalam kalangan pelajar di Universiti Awam Malaysia. Tesis PhD. Universiti Kebangsaan Malaysia. Tidak diterbitkan

Müller, V. C., \& Bostrom, N. (2016). Future progress in artificial intelligence: A survey of expert opinion. In V. C. Müller (Ed.), Fundamental issues of artificial intelligence (pp. 553-570). Springer.

Prastiwi, CHW, Nia Pujiawati. (2019).Penggabungan Artificial Intelligence dan Kecerdasan Alami dalam Pembelajaran Keterampilan Menulis Bahasa Inggris. Prosiding Seminar Nasional Pascasarjana UNNES).

Rosli, Tasnim; Muniandy, Yogenathan; Jasmi, Kamarul Azmi (2019). "Media Sosial dan Impak Tingkah Laku Menurut Islam" in Jasmi, Kamarul Azmi (Ed.), Prosiding Seminar Sains Teknologi dan Manusia 2019 (SSTM'19) pada 15hb. Disember 2019 di DP3, N29, Fakulti Kejuteraan Kimia dan Tenaga, UTM. Program anjuran Akademi Tamadun Islam, FSSK, UTM, p. 115-130.

Russel, S. J, \& Norvig, P. (2016). Artificial Intelligence: A Modern Approach. Kuala Lumpur, Malaysia: Pearson Education Limited.

Shabbir, J., \& Anwer, T. (2015). Artificial Intelligence and its Role in Near Future. ArXiv:1804.01396 [Cs], 14(8), 1-11.

Siti Ezaleila Mustafa \& Azizah hamzah, (2010), Media Sosial: Tinjauan Terhadap Laman Jaringan Sosial Dalam Talian Tempatan, Jurnal Pengajian Media Malaysia Jilid 12 Malaysian Journal of Media Studies Volume 12 Vol. 12, No. 2, Pages 37-52.

Strelkova, O. \& Pasichnyk, O. (2017). Three Types of Artificial Intelligence; Khmelnitsky National University: Khmelnytskyi, Ukraine Teh, Nee-Joo. 2017. Artificial Intelligence in Canada 2017. https://admin.ktn-uk.co.uk/app/uploads/2018/11/2017-CanadaAIExpert-Mission-Report.pdf (retrieved $-17^{\text {th }}$ Feb 2021).

Vyas, Manish., Thakur, Sourav., Riyaz, Bushra. Bansal, Kuldeep K., Tomar, Bhupendra, \& Mishra, Vijay. (2018). Artificial Intelligence: The Beginning of a New Era in Pharmacy Profession. Asian Journal of Pharmaceutics, 12 (2): 72-76

Walsh, T. (2016). The singularity may never be near. arXiv preprint arXiv:1602.06462.

Welsh, Bridget (2018), "Saviour" Politics and Malaysia's 2018 Electoral Democratic Breakthrough: Rethinking Explanatory Narratives and Implications. Journal of Current Southeast Asian Affairs, 37, 3, 85-108. 